\author{
VÁCLAV ŠTĚPÁNEK* \\ Filozofická fakulta Masarykovy univerzity \\ Brno, Česká republika
}

\title{
BÁDÁNÍ O HISTORII, KULTUŘE A LITERATUŘE JIHOSLOVANSKÝCH NÁRODU゚ NA FILOZOFICKÉ FAKULTĚ V BRNĚ
}

\begin{abstract}
Studie podává přehled bádání na poli historie, kultury a literatury jihoslovanských národů na filozofické fakultě v Brně od jejího založení v roce 1919 do současnosti. Seznamuje s institucionalizací jihoslovanských a vůbec balkanistických studií na Masarykově univerzitě. Připomíná nejvýznamnější osobnosti brněnské slavistiky, které se zasloužily o rozvoj bádání v tomto směru a upozorňuje na zásadní výsledky vědecké produkce brněnských slavistů a balkanistů. Konstatuje, že činnost vědců a pedagogů filozofické fakulty brněnské univerzity směrem $\mathrm{k}$ Balkánu a jihoslovanské problematice byla a je mimořádně košatá. Brněnská slavistika dokázala s nadhledem a nestranností vytvářet objektivní díla vysoké odborné úrovně a vychovat také desítky nových absolventů jihoslovanských a balkanistických studií, z nichž mnozí, často i mimo akademickou sféru, přispívají at již jako překladatelé, diplomaté či lidé zabývající se ekonomickými problémy, k porozumění mezi českým prostředím a jihoslovanskými národy.
\end{abstract}

Klíčová slova: slavistika, jižní Slované, jihoslovanská bádání, balkanistika, Brno, Masarykova univerzita

\section{Jihoslovanské tematika na Filozofické fakultě Masarykovy univerzity v meziválečném období}

Slavistická bádání, zaměřená směrem $\mathrm{k}$ Balkánu, především ovšem $\mathrm{k}$ tomu slovanskému, byla na Filozofické fakultě brněnské univerzity př́tomna již od jejího založení v roce 1919. Filozofická fakulta tehdy patřila mezi zakládající fakulty druhé české univerzity, o jejíž vznik se významně zasloužil první prezident československé republiky Tomáš Garrigue Masaryk, po němž také brněnská univerzita dostala své jméno. T. G. Masaryk, sám univerzitní profesor, totiž již v 90. letech 19. století zdůrazňoval potřebu co nejširší konkurence ve vědeckém životě a upozorňoval na fakt, že jediná česká univerzita - pražská (do roku 1918 Karlo-Ferdinandova, po vzniku Československa již jen Karlova) - nutně potřebuje ke svému rozvoji konkurentku v národním rámci. Snaha prosadit zřízení druhé české univerzi-

*v.stepanek@int-cz.com 
ty se stala jednou z priorit nejen jeho politické činnosti, ale i politického boje českých kruhů v tehdy německou menšinou vedeném Brně. Došla však naplnění až po vzniku Československé republiky v roce 1918. Filozofická fakulta tak jako součást nové Masarykovy univerzity dostala do vínku úkol stát se druhým ohniskem národní vzdělanosti a osvěty. V pamětní zakládací listině z roku 1919 jí bylo uloženo, aby „žila, mohutněla a kvetla v ušlechtilém závodění se starší sestrou pražskou".${ }^{1}$ A to se jí dařilo mj. právě v přístupu k jihoslovanské problematice.

Tak hned první profesor slovanských literatur na brněnské filozofické fakultě Jiř́ Horák (1884-1975; působil zde v letech 1922-1926)² věnoval pozornost srbocharvátské literárněvědné problematice. Zásadní dílo v bádání o jihoslovanských literaturách však učinil až jeho nástupce Frank Wollman (1888-1969), vynikající znalec jihoslovanských literatur, jenž přišel z bratislavské univerzity do Brna jako Horákův nástupce v roce 1928 a učil na fakultě až do svého odchodu do důchodu v roce 1959. Wollman osobně znal velké postavy tehdejšího charvátského, o něco méně i srbského písemnictví, dobře se ale orientoval také v literatuře bulharské a slovinské, což prokázal již v dílech, v nichž analyzoval dramatické umění Srbů, Charvátů Slovinců a Bulharů - v knihách Srbocharvátské drama (Bratislava: Filosofická fakulta University Komenského [dále jen FF UK], 1924, 408 s.), Slovinské drama (Bratislava: FF UK, 1925, 322 s.) a Bulharské drama (Bratislava: FF UK, 1928, 166 s.), později pak v syntéze Dramatika slovanského jihu (Praha: Slovanský ústav, 1930, 248 s.). Jihoslovanské autory až do jeho doby a tendence vývoje tamních literatur představil ve svém kardinálním komparatistickém opusu nazvaném Slovesnost Slovanů (Praha: Vesmír, 1928, 263 s.; 2. vydání - Brno: Tribun EU, 2012, 476 s., eds. I. Pospíšil a M. Zelenka). ${ }^{3}$ Wollmanův živý zájem o jihoslovanskou literaturu dosvědčuje mimo jiné i rozsáhlá studie Njegošùv deseterac (Slavia: Praha, roč. 9, 1930-1931, č. 4, s. 737-791) či jeho bohatá recenzní činnost recentních děl jihoslovanských autorů.

Významným badatelem, zejména pokud jde o bulharskou literaturu, byl na předválečné brněnské filozofické fakultě také ruský bílý emigrant Sergej Grigorijevič Vilinskij (1876-1950), ${ }^{4}$ jenž na fakultu přišel na pozvání

\footnotetext{
${ }^{1}$ https://www.phil.muni.cz/o-nas/historie-fakulty\#zalozeni.

${ }^{2}$ Více o něm viz HLÔŠKOVÁ, H. - POSPÍŠIL, I. - ZELENKOVÁ, A.: Slavista Jiř́ Horák $v$ kontexte literatúry a folklóru. Brno: Česká asociace slavistů, 2012, 265 s.

${ }^{3} \mathrm{~V}$ tomto druhém vydání byla publikována také zásadní studie a Wollmanově pojetí slovanských literatur z pera editorů. Viz POSPÍŠIL, I. - ZELENKA, M.: Střední Evropa jako křižovatka metodologii: Slovesnost Slovanů Franka Wollmana - tradice a souvislosti (nad druhým českým vydáním). In: Wollman, F., Slovesnost Slovanů. Brno, Tribun EU, s. 23-68.

${ }^{4}$ Více o něm srov. POSPÍŠIL, I.: Brněnský př́běh Sergije Vilinského. In: Migrácia obyvatelov východnej Európy na územie Slovenska a Čiech (prvá polovica 20. storočia). Prešov, Filozofická fakulta Prešovskej univerzity, 2009, s. 186-193.
} 
věhlasného paleoslavisty Václava Vondráka (1859-1925) z Bulharska, kam upchl z bolševického Ruska a kde se také podrobně seznámil s tamní literaturou. Výsledkem jeho bulharistických zájmů byla monografie Petko Jurdanov Todorov (život a dílo) (Brno: Filosofická fakulta s podporou Ministerstva školství a národní osvěty, 1933, 151 s.), v níž autor kromě samotného tvůrce široce komentuje a analyzuje vývoj soudobé bulharské literatury.

\section{Institucionalizace jihoslovanských studií po druhé světové válce}

Slavistická studia zaměřená na slovanský jih ovšem v meziválečné době a ani dlouho po druhé světové válce (od 17. listopadu 1939 do května roku 1945 byly české vysoké školy uzavřeny, v letech 1960-1989 byla brněnská univerzita z ideologických důvodů přejmenována na Univerzitu Jana Evangelisty Purkyně) nebyla nijak institucionalizovaná. Odborníci zabývající se jihoslovanskou problematikou působili od roku 1921 jak v rámci slovanského semináře, tak i jiných kateder, stejně tak po válce, kdy slovanský seminář zanikl a částečně jej nahradila nově zřízená katedra slavistiky, od roku 1956 rozšiřená a přejmenovaná na katedru slovanské filologie a srovnávacího indoevropského jazykozpytu. V rámci ní byly občas otevírány studijní obory bulharistika a serbokroatistika. I tato katedra ale později zanikla a své skutečné institucionální podoby se jihoslovanská studia dočkala teprve za působení historika Josefa Macůrka (1901-1992), ${ }^{5}$ zakladatele historického balkanistického výzkumu na brněnské filozofické fakultě, a jeho vrstevníka, bulharisty, turkologa a balkanologa Josefa Kabrdy (1906-1908). ${ }^{6}$ Právě ten totiž, s Macůrkovým přičiněním, založil při tehdejší katedře historie a etnografie střední, jihovýchodní a východní Evropy v roce 1966 kabinet balkanistiky a hungaristiky, jenž na fakultě až do roku 1995 koordinoval balkanistický výzkum. ${ }^{7}$ Je samozřejmě logické, že kabinet založený při historicko-etnografické katedře vykazoval bohatou badatelskou činnost především v oblasti historické balkanistiky: zabýval se dějinami jihoslovanských a vůbec balkánských národů a také česko-slovensko-jihoslovanskými vztahy, neopomíjel pochopitelně ani etnografická bádání s balkánskou tematikou. Dủležitou součástí produkce některých jeho pracovníků však byla také díla

${ }^{5}$ Více o něm viz VLČEK, R.: Josef Macůrek. Praha: Akademie věd České republiky [dále jen AV ČR], 2015.

${ }^{6}$ O něm viz např. PRAŽÁK, R.: Josef Kabrda (3. II. 1906-27. V. 1968. Život a dílo). In: Sborník prací filosofické fakulty brněnské university, Brno, Universita J. E. Purkyně, 1969, C 16, s. 7-30.

${ }^{7} \mathrm{O}$ založení kabinetu a jeho činnosti více např. HLADKÝ, L.: Balkanistika - předmět zkoumání, historie a současnost této vědní specializace In: Semotamová, E. (ed.), Cestou dějin. K poctě prof. PhDr. Svatavy Rakové, CSc. Praha, Historický ústav AV ČR, 2007, s. 77-88. 
literárně vědná a literárně historická. $\mathrm{K}$ tomu všemu ale kabinet zajištoval i výuku jihoslovanských jazyků - bulharštiny a srbocharvátštiny, k nimž bývaly připojeny také základy slovinštiny a makedonštiny.

$\mathrm{V}$ roce 1995 na brněnské filozofické fakultě nově vznikl péčí mezinárodně uznávaného rusisty a slavisty Iva Pospíšila ústav slavistiky. V jeho rámci byla sjednocena všechna dosavadní pracoviště zabezpečující studium rozličných slovanských jazyků a literatur. Po jistém váhání byl do nového ústavu včleněn také kabinet balkanistiky a hungaristiky, jenž se v roce 2004 uvnitř ústavu slavistiky etabloval pod novým názvem Seminář jihoslovanských filologií a balkanistiky. ${ }^{8}$

\section{Historická produkce jihoslovanských a balkanistických studií na brněnské filozofické fakultě}

Spoluzakladatel kabinetu Josef Macůrek nebyl typickým balkanistou, a pokud již o balkánských dějinách psal, věnoval se spíše historii neslovanských národů. Poukázat můžeme především na jeho monografie Rumunsko ve své minulosti a př́tomnosti (Praha: Orbis, 1930) či Dějepisectví evropského východu (Praha: Historický klub, 1946). Macůrek se zabýval rovněž osobností albánského národního hrdiny Skanderbega ${ }^{9}{ }^{9}$ vzájemnými kontakty českého krále Jiřího z Poděbrad a moldavského knížete Štěpána III. Velikého (Ștefan cel Mare) ${ }^{10}$ a dalšími otázkami česko-rumunských styků staršího i novějšího období. K těmto rumunistickým studiím je třeba zařadit i Macůrkův referát na balkanologickém kongresu v Sofii (1969, 1970).

Macůrkův vrstevník Josef Kabrda, první vedoucí kabinetu balkanistiky a hungaristiky (1966-1968, zemřel během studijního pobytu v Ankaře), byl historikem, jenž dokázal na světové úrovni traktovat balkánské dějiny prismatem tureckých pramenů. Na jejich základě (bádal zejména v bulharských a později přímo $\mathrm{v}$ tureckých archivech) prokázal např. v bulharsky psaném

${ }^{8}$ Viz KREJČÍ, P.: Seminář jihoslovanských filologií a balkanistiky. In: Pospíšil, I. (ed.)., Ústav slavistiky FF MU. Východiska - koncepce - výhledy. Brno, Čižmár-Partner, 2005, s. 37-48; týž, Problematika výuky jihoslovanských jazyků na Filozofické fakultě Masarykovy univerzity. In: Pospíšil, I. - Zelenka, M. (eds.), Česká slavistika 2008. Brno - Praha, Česká asociace slavistů, Literárněvědná společnost, pobočka Praha, Academicus, 2008, s. 91-100.

${ }^{9}$ MACŮREK, J.: Georg Skanderbeg, Albanien und die tschechischen Länder. Studia Albanica, Tirana: Universita d'Etat, 1967, s. 44-51; týž, Georg Skanderbeg: Zur 500. Wiederkehr des Todes des grossen Kämpfers des albanischen Volkes für Freiheit und Unabhängigkeit. In: Sborník prací Filosofické fakulty brněnské university, Brno, Filosofická fakulta brněnské university, 1968,22 s.

${ }^{10}$ Např. MACŮREK, J.: Zwei Entwürfe aus der 2. Hälfte des 15. Jahrhunderts für die Organisierung Europas: des böhmischen Königs Georg von Podiebrad und des moldauischen Fürsten Stephan des Grossen. Revue Roumaine d'Histoire, Bucarest: Académie de la République Socialiste de Roumanie, 1969, s. 502-513. 
rozboru termínu „raja” (tur. râya), že tento termín měl až do 18. století spíše sociální obsah a že se jej užívalo v osmanské ř́ŕsi nejen pro křestanské obyvatelstvo, nýbrž pro veškeré obyvatelstvo bez rozdílu náboženství a národnosti. ${ }^{11}$ Ve studii Turecké prameny $k$ bulharským dějinám a jejich zpracování $v$ Bulharsku (Časopis Archívní školy, Praha, roč. 15-16, 1939, s. 200-231), podobně jako v pozdější práci Les problèmes de l'étude de l'histoire de la Bulgarie à l'époque de la domination Turque (Byzantinoslavica, Praha, roč. XV, 1954, č. 2, s. 173-208) a celé řadě dalších na základě studia tureckých pramenů omítl četná klišé v traktování bulharských a dalších dějin balkánských národů. K těmto pracím lze připočíst jeho četné studie k dějinám národů Balkánu i zevrubné reference o vývoji historiografie $\mathrm{v}$ různých balkánských zemích, $\mathrm{v}$ nichž, mimo jiné, jako první poukazoval na úspěchy mladé makedonské historiografie. Studiu osmansko-tureckého feudalismu v Makedonii (zejména v 15. a 16. století) ostatně věnoval i sám značné vědecké a badatelské úsilí. Významnou složkou jeho badatelské práce byly edice, rozbory a výklady tureckých hospodářsko-správních zákoníků (tzv. kánúnnáme) pro balkánské a podunajské oblasti osmanské říše. Podle názorů některých badatelů došel na tomto poli ze všech evropských badatelů nejdále. ${ }^{12} \mathrm{~V}$ posledních letech svého života se zabýval také systematickým výzkumem feudální renty v osmanské říši. Jeho životní dílo, spis Le systéme fiscal de léglise orthodoxe dans lEmpire ottoman. Sous le jours des documents turcs (Brno: Opera Universitatis Purkinianae Brunensis. Facultas philosophica, 1969, 321 s.), které ovšem vyšlo až posmrtně, se zabýval církevním zdaněním bulharského obyvatelstva ve světle osmanských pramenů s tím, že v něm také shrnul své předchozí poznatky o úloze a postavení pravoslavné církve v osmanském impériu.

Problematice Východní otázky a z ní plynoucích otázek národnostních, jakož i tematice národních programů v jihovýchodní Evropě či myšlence balkánské federace a spolupráce se v rámci kabinetu balkanistiky a hungaristiky věnoval Josef Kolejka (1924-2015). ${ }^{13}$ Jeho zásadními pracemi na tomto poli jsou rozsáhlá rozprava "Východní” nebo „balkánská otázka" v 19. století (do r. 1878). Stanovisko mezinárodního socialistického hnutí (In: Hejl, F. - Kolejka J. (eds.), Otázky dějin střední a východní Evropy II. Brno, Univerzita J. E. Purkyně, 1975, s. 149-221) a její dvě pokračování, v nichž tuto problematiku dovádí do roku 1912,14 a monografie Balkánská

${ }^{11}$ KABRDA, J.: Raja. Izvestija na Bălagarskoto istoričesko družestvo v Sofija, roč. 14-15, 1937, s. 172-185.

${ }^{12}$ Viz PRAŽÁK, R.: c. d., s. 16.

${ }^{13}$ Více o jeho balkanistických bádáních viz HLADKÝ, L.: Jižní Slované a Balkán v díle Josefa Kolejky. In: Historik Josef Kolejka. Brno, Masarykova univerzita a Společnost přátel jižních Slovanů, 2004, s. 21-25.

${ }^{14}$ KOLEJKA, J.: „Východní otázka” nebo „balkánská otázka” v letech 1878-1907: stanovisko mezinárodního socialistického hnutí. In: Sborník prací Filozofické fakulty brněnské 
otázka 1908-1914. Mezinárodní socialistické hnutí o mladoturecké revoluci a o balkánských válkách (Brno: Univerzita J. E. Purkyně, 1979, 143 s.). Novodobého vývoje jihoslovanských národů se Kolejka dotknul také v monografii Národy habsburské monarchie v revoluci 1848-1849 (Praha: Svoboda, 1989, 467 s.) a v celé řadě dalších studií. ${ }^{15}$

Výstavní skříní publikační činnosti badatelů spojených s kabinetem balkanistiky a hungaristiky byla vedle výzkumu historie (nejen) jihoslovanských národů vždy i tematika dějin česko-slovensko-jihoslovanských vztahů, jíž se zabývali také Jiří Cvetler (1902-1991), František Jordán (1921-1979), Ivan Dorovský (1935) a Ctibor Nečas (1933). V současnosti se těmto tématům věnují zejména Ladislav Hladký (1958) a Václav Štěpánek (1959) a jejich žáci mladé vědecké generace: Jana Škerlová, ${ }^{16}$ Pavel Zeman, ${ }^{17}$ Jonáš Pospíchal ${ }^{18}$ či Kateřina Kolářová ${ }^{19}$.

univerzity, řada historická (C), Brno, Universita J. E. Purkyně v Brně - filozofická fakulta, roč. 23-24, 1975, č. 21-22, s. 229-290; týž, Balkánská otázka v letech 1909-1912. Slovanský přehled, Praha: Academia, roč. 61, 1975, č. 4, s. 265-281.

${ }^{15}$ KOLEJKA, J.: „Druhé Rusko” a hnutí jihoslovanských národů 1875-1878. Slovanský přehled, Praha: Academia, roč. 64, 1978, č. 4, s. 302-311; týž, Jižní Slované a Velká východní krize 1875 až 1878. Evropští socialisté o východní otázce. Slovanský přehled, Praha: Academia, roč. 62 , 1976, č. 2, s. 111-127.

${ }^{16}$ Jana ŠKERLOVÁ (rozená Hrabcová) je autorkou několika studií o jugoslávských dějinách v letech mezi první a druhou světovou válkou a také o česko-jugoslávských stycích v té době. Nejnověji vydala obsáhlou monografii nazvanou Věrnost za věrnost. Československojugoslávské politické vztahy v letech 1929-1934. Prání, rozpory, realita. Praha: Historický ústav AV ČR, 2016, $384 \mathrm{~s}$.

${ }^{17}$ Pavel ZEMAN se zabývá zejména tzv. českou kulturní invazí do Bulharska, tedy příchodem Čechů do Bulharska poté, co se v roce 1878 osamostatnilo. Srov. např. jeho práce Motivy české inteligence k př́chodu do Bulharska. In: Čolakova, Ž. - Avramova, C. - Burova, A. - Borislov, B. - Kuzmova, M. - Dimitrova, S., Sbornik s dokladi ot petata nacionalna srešta na bochemistite. Plovdiv, Universitetsko izdatelstvo „Paisij Chilendarski”, 2016, s. 63-72; týž, Čeští učitelé na gymnáziích v Bulharsku v letech 1878-1912. In: Przybylski, M. - Šaur, J. (eds.), Mladá slavistika: současné trendy ve výzkumu slovanských literatur, jazyků a kultur. Brno, Masarykova univerzita, 2014. s. 147-162 aj.

${ }^{18}$ Jonáš POSPÍCHAL publikuje na základě zevrubných archivních výzkumů příspěvky o spolupráci československých a jugoslávských exilových představitelů za druhé světové války. Srov. např. Odtažitost a vyčkávání. Vztahy exilových vlád Československa a Jugoslávie v letech 1941-1943. Slovanský přehled, Praha: Academia, roč. 102, 2016, č. 3, s. 451-502; týž, Spojenec očima spojence: jugoslávské vojsko $v$ zahraničně politických úvahách Československa $v$ letech 1936-1938. In: Sborník vystoupení na studentské konferenci, uspořádané Radou pro mezinárodní vztahy v rámci odkazu celoživotní práce Jiř́ho Dienstbiera, jejíž VII. ročník se konal 28. května 2013 v Senátu Parlamentu České republiky. Praha, Rada pro mezinárodní vztahy, 2013. s. 26-46.

${ }^{19}$ Kateřina KOLÁŘOVÁ se zevrubně zabývá činností československo-jihoslovanských spolků v meziválečné době. Srov. např. Československo-jugoslávské vztahy v meziválečném Brně. Kultúrne dějiny, Rožumberok: Verbum, roč. 7, 2016, č. 2, s. 217-256; Časopisy Československo-jihoslovanské ligy: sonda do pramenů k dějinám meziválečných československo-jugo- 
J. Cvetler věnoval několik studií osobnosti Konstantina Jirečka a jeho stykům s jihoslovanským prostředím, pojednáními přispěl k dějinám českobulharských vztahů, ${ }^{20}$ významné jsou i jeho práce (byl především právním historikem) o Zákoníku Štěpána Dušana. F. Jordán publikoval řadu studií o česko-charvátských a česko-slovinských vztazích staršího i novějšího období. ${ }^{21}$

Dějinám česko-jihoslovanských kulturně politických vztahů v 19. a ve 20. století je věnována také většina historických děl I. Dorovského. Základní prací v tomto směru je jeho šířeji balkanisticky zaměřená monografie České země a Balkán. Kapitoly z dějin česko-makedonských a makedonsko-českých styků (Brno: Universita J. E. Purkyně - filosofická fakulta, 1973, 250 s.) a publikace o zakladateli moderní české historické balkanistiky nazvaná Konstantin Jireček. Život a dílo (Brno: Universita J. E. Purkyně - filosofická fakulta, 1983, 232 s.). Dorovský se zabýval velmi zevrubně také problematikou etatizace makedonského národa. Vyvrcholení makedonských národně osvobozeneckých aktivit, tzv. Ilindenskému povstání v roce 1903, tak věnoval sborník Ilinden je $v$ nás (Brno: Albert, 2003, 117 s.). Nad dějinami Makedonie se zamýšlel a klíčové momenty makedonské historie mapoval v knize Makedonie: zrození nebo obrození národa? (Boskovice: Albert, 1995, 77 s.). Př́spěvkem ke zkoumání osudů uprchlíků (zejména dětí) z Egejské Makedonie do Československa během občanské války v Řecku v letech 1947-1949 jsou Dorovským připravené a redigované dvě monografie Makedonci žijí mezi námi I. a II. (Brno: Společnost přátel jižních Slovanů, 1998, 351 s.; Brno - Boskovice: Společnost přátel jižních Slovanů a Albert, 2008, 227 s.), jež obsahují odborné studie o příčinách a průběhu vlastní emigrace i o životě makedonských uprchlíků v Československu, ale také vzpomínky aktérů těchto neštastných dějů. Podobně se Dorovský zabýval také charvátskou diasporou na Moravě ve sborníku studií a vzpomínek nazvaném Charváti ještě žijí mezi námi (Brno: Společnost přátel jižních Slovanů v České republice, 1996, 123 s.), který sestavil a redigoval.

slávských styků. Porta Balkanica, Brno: Občanské sdružení Porta Balkanica, roč. 7, 2015, č. 1, s. 47-62.

${ }^{20}$ Např. CVETLER, J.: Die Tätigkeit der tschechischen Juristen in Ostrumelien 1880 1885 als ein Beitrag zum Aufbau des bulgarischen Staates. Association internationale d'études du sud-est Européen, Sofia: Éditions de l'Académie Bulgare des science, roč. IV, 1969, s. 665-676; týž, Český dopisovatel v srbsko-bulharské válce r. 1885. Slovanské historické studie, Praha: Československá akademie věd, 1960, č. 3, s. 263-312.

${ }^{21}$ Např. JORDÁN, F.: Češi a Charváti v tureckých válkách 16. století. In: Sborník prací Filozofické fakulty brněnské univerzity: řada historická (C), Brno, Filosofická fakulta brněnské university, roč. 10, 1961, č. 8, s. 161-173; týž, Češi a Slovinci v 19. a na začátku 20. století. (Jejich vztahy veřejné a politické). In: Otázky dějin střední a východní Evropy, Brno, Univerzita J. E. Purkyně, 1971, s. 263-292. 
Plodným autorem, pokud jde o dějiny česko-jihoslovanských styků, byl také J. Nečas. Na tomto místě můžeme zmínit např. jeho knihu Mezi muslimkami. Působení úředních lékařek $v$ Bosně a Hercegovině v letech 18921918 (Brno: Masarykova univerzita, 1992, 137 s.) a především několik monografií, v nichž Nečas jako jediný z českých historiků podrobně zkoumal ekonomické vztahy českých zemí a Balkánu - Balkán a česká politika: Pronikání rakousko-uherského imperialismu na Balkán a česká buržoazní politika (Brno: Universita J. E. Purkyně, 1972, 160 s.), Na prahu české kapitálové expanze (Brno: Univerzita J. E. Purkyně, 1987, 130 s.), Podnikání českých bank $v$ cizině 1898-1918. Rozpínavost českého bankovního kapitálu ve střední, jihovýchodní a východní Evropě v období rakousko-uherského imperialismu (Brno: Masarykova univerzita, 1993, 137 s.).

Celou řadu studií o česko-slovinských, česko-bosenskohercegovských a obecně česko-jihoslovanských vztazích publikoval L. Hladký, jenž byl také editorem a spoluautorem monografie Vztahy Čechů s národy a zeměmi jihovýchodní Evropy (Praha: Historický ústav AV ČR, 2010, 367 s.), na níž se podílelo i několik mladších absolventů brněnských balkanistických studií (Petr Stehlík, Jana Hrabcová). V této knize je shrnuta summa poznání o českých pracích zabývajících se styky příslušníků českého národa s balkánskými zeměmi. L. Hladký je také autorem původních českých syntéz o dějinách jednotlivých balkánských zemí. Zmínit je nutno zejména jeho práci Bosenská otázka v 19. a 20. století (Brno: Masarykova univerzita, 2005, 388 s.), jež komplexností shromážděných faktů a řešených otázek byla prvním zevrubným zpracováním bosenské problematiky nejen v českých zemích. Hladký je také spoluautorem velkých syntéz Dějin jihoslovanských zemí (Praha: Lidové noviny [dále jen LN], 1998, 2. vydání 2009, 758 s.), Dějin Albánie (Praha: Nakladatelství LN, 2008, 716 s.) a Dějin Slovinska (Praha: Nakladatelství LN, 2011, 441 s., sám pak sepsal stručné dějiny tohoto státu, vydané pod názvem Slovinsko. Praha: Libri, 2010, 190 s.). Pro poznání přínosu brněnské filozofické fakulty do balkanistického diskurzu je významná také Hladkého studie Př́spěvek k dějinám české historické balkanistiky. Tradice tzv. brněnského střediska (In: Historik na Moravě. Profesoru Jiřímu Malířovi, předsedovi Matice moravské a vedoucímu Historického ústavu FF MU, věnují jeho kolegové, přátelé a žáci k šedesátinám. Brno, Matice moravská, 2009 s. 195-206), obecně pak Hladký pojednal o balkanistických studiích v obsáhlejší rozpravě Balkanistika (jihovýchodoevropská studia): předmět zkoumání, historie a současnost této vědní specializace (In: Cestou dějin: k poctě prof. PhDr. Svatavy Rakové CSc. Praha, Historický ústav AV ČR, 2007 s. 77-89).

Na nové a nejnovější dějiny Balkánu, zejména na oblast označovanou jako postjugoslávský prostor, se odborně soustředuje V. Štěpánek. V řadě studií analyzoval příčiny, které vedly ke vzrůstu etnického nacionalismu v 
Jugoslávii a rozebíral krizové politické události 80. a počátku 90. let v jugoslávské federaci, zejména pak v Srbsku. ${ }^{22}$ Badatelský zájem orientuje také na analýzu dějů $\mathrm{v}$ etnicky a nábožensky složitém území Kosova (zásadní $\mathrm{v}$ tomto směru je jeho monografie Jugoslávie - Srbsko - Kosovo. Kosovská otázka ve 20. století. Brno: Masarykova univerzita, 2011, 472 s.). Přehled dějů Východní otázky podal v publikaci Východní otázka. Od počátků do konce 60. let 19. století (Brno: Masarykova univerzita, 2014, 150 s.). Publikuje také o českých menšinách na Balkáně. ${ }^{23}$

Řadu po faktografické i metodologické stránce podnětných studií o

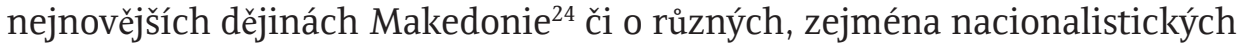
konceptech dějin Srbska, Chorvatska a Bosny a Hercegoviny ${ }^{25}$ publikoval v posledním období Petr Stehlík (1978), jenž v monografii Bosna v chorvatských národně-integračních ideologiích 19. století (Brno: Masarykova univerzita, 2013, 218 s.; vyšla také v upraveném charvátském překladu pod názvem Između hrvatstva i jugoslavenstva: Bosna u hrvatskim nacionalno-integracijskim ideologijama 1832-1878. Zagreb: Srednja Europa, 2015, 211 s.) představuje pojetí a obraz Bosny v pracích předních charvátských národních ideologů 19. století, počínaje představiteli ilyrismu, přes příslušníky tzv. „původního či autentického" jihoslovanství až k tvůrcům pravašské ideologie.

Důležitou součástí tvưrčí činnosti badatelů z brněnské filozofické fakulty byla po pádu komunistického režimu v Československu v roce 1989

${ }^{22}$ Např. ŠTĚPÁNEK, V.: VIII. zasedání Ústředního výboru Svazu komunistů Srbska - přelomové datum moderní jugoslávské historie. Př́spèvek k objasnění mocenského vzestupu Slobodana Miloševiće. Studia historica Brunensia, roč. 53 2005, s. 179-194; týž, Srbské snahy o revizi principů jugoslávské ústavy z roku 1974 (Od konce šedesátých let 20. století do 8. zasedání Ústředního výboru Svazu komunistů Srbska v zárí 1987). Slovanské historické studie, roč. 31, 2006, 101-136; týž, Církev a stát a Aktuální problémy srbské společnosti. In: Štěpánek, V. (ed.), Současné Srbsko, politika, kultura, Evropská unie. Brno, Albert, 2007, s. 93-101; s. 118134; týž, Několik pohledi̊ na nacionalismus - jeden z faktorů rozpadu Jugoslavie. In: Balkán a nacionalismus. Labyrintem nacionální ideologie. Brno, Porta Balkanica, 2012, s. 39-55 aj.

${ }^{23}$ Např. ŠTĚPÁNEK, V.: Česká kolonizace Banátské vojenské hranice na území srbskobanátského hraničářského pluku. In: Od Moravy k Moravě. Z historie česko-srbských vztahů v 19. a 20. století. Brno, Matice moravská, 2005, s. 73-102.

${ }^{24}$ STEHLÍK, P.: Makedonsko-albánský spor ohledně založení a činnosti albánské univerzity $v$ Tetovu (1994-2004). Slovanský přehled, Praha: Academia, roč. 92, 2006, č. 3.

${ }^{25}$ STEHLÍK, P.: Slovački apostol jugoslavenstva: Bogoslav Šulek i njegova polemika s Vukom Karadžićem. In: Krejčí, P. - Krejčová, E. (eds.), Bogoslav Šulek a jeho filologické dílo / Bogoslav Šulek i njegov filološki rad. Brno, Česká asociace slavistů - Ústav slavistiky FF MU, 2016, s. 21-28; týž, „Srbové všichni a všude”: Karadžićova jazyková definice srbství jako východisko srbského nacionalismu. In: Krejčí, P. -Krejčová E. (eds.), Výuka jihoslovanských jazyků a literatur v dnešní Evropě. Brno, Sojnek, 2015, s. 29-34; týž, Bosna, Zach i Načertanije: O nekim aspektima programa Ilije Garašanina iz 1844. godine. Slavistika, Beograd, roč. 18, 2014, s. 353-360; týž, Bosna a Hercegovina v ideologii chorvatských ustašovců. In: Bosna 1878-2008: Sborník př́íspěvků z konference konané ve dnech 29.-30. května 2008 v Ústí nad Labem. Ústí nad Labem, Univerzita J. E. Purkyně, 2010, s. 151-161. 
také jistá rehabilitace bádání o prvním československém prezidentovi Tomáši Garrigue Masarykovi a jeho poměru k Jihoslovanům, nebot to byly zejména jeho intervence v rakousko-uherských delegacích a v rakouském parlamentu o jihoslovanských záležitostech, které jej mezinárodně proslavily. Statě o stycích Tomáše G. Masaryka s Jihoslovany psali zejména L. Hladký a V. Štěpánek. ${ }^{26}$

Na brněnské filozofické fakultě vznikla také celá řada kolektivních monografií či sborníků o česko-jihoslovanských vztazích a stycích. Z posledních let jsou důležité zejména dva díly editovaných dvoujazyčných česko-srbských monografií obsahujících více než 30 studií o česko-srbských kontaktech s př́značným názvem Od Moravy k Moravě I. a II. (Brno: Matice moravská ve spolupráci s Maticí srbskou, 2005, 312 s.; Novi Sad: Matice srbská ve spolupráci s Maticí moravskou, 2011, 430 s.), které vyšly především péčí odborníků z filozofické fakulty. První svazek redigovali L. Hladký a V. Štěpánek, druhý díl připravila Matice srbská, jeho českou část redigoval V. Štěpánek. Ústav slavistiky byl hlavním garantem vydání kolektivní monografie vzešlé ze sympozia uskutečněného v Brně na jaře roku 2007 pod názvem Současné Srbsko - politika, kultura, EU (Brno: Albert, 2007, 160 s.). Publikace redigovaná V. Štěpánkem obsahuje deset př́spěvků, zkoumajících aktuální srbské politické a společenské klima, problémy integrace Srbska do evropských politických i bezpečnostních struktur, českou politiku ve vztahu k Srbsku, význam př́mé meziregionální spolupráce na přibližování Srbska evropské integraci a zabývá se i dalšími palčivými problémy. Na tuto kolektivní monografii do jisté míry navázal sborník př́spěvků ze sympozia ke 200. výročí narození Františka Alexandra Zacha, propagátora mezislovanské vzájemnosti, zakladatele srbského vojenského školství, prvního srbského generála a jedné z nejvýznamnějších osobností v rámci historie

${ }^{26}$ Např.: HLADKÝ, L.: Ohlas Masarykova sociálního učení u Slovinců. In: T. G. Masaryk a sociální otázka. Hodonín, Masarykovo muzeum v Hodoníně, 2002, s. 91-99; týž, T. G. Masaryk a jižní Slované: konstanty a proměnné v rámci starého príběhu. In: T. G. Masaryk a Slované. Praha, Historický ústav, 2013, s. 237-252; týž, Masarykovy problémy s Jihoslovany. In: Evropa mezi Německem a Ruskem. Sborník prací k sedmdesátinám Jaroslava Valenty. Praha, Historický ústav AV ČR, 2000, s. 293-299; týž, T. G. Masaryk i Bosna i Hercegovina. (Prilog historiji bosansko-čeških odnosa). Prilozi: Univerzitet u Sarajevu - Institut za istoriju, roč. 30, 2001, s. 117-141. ŠTĚPÁNEK, V.: Failed Attempts to Improve Relations between Serbia and Austria-Hungary on the Eve of the First World War as Reflected in Czech Archival Records. In: The Serbs and the First World War 1914-1918. Belgrade, Serbian Academy of Sciencea and Arts, 2015, s. 219-234; týž, Tomáš G. Masaryk a Srbové z království před první světovou válkou. In: Doubek, V. - Hladký, L. - Vlček, R. (eds.), T. G. Masaryk a Slované. Praha, Historický ústav, 2013, 297-312; týž, Neúspěšné pokusy o smír - česká politická reprezentace, Nikola Pašić a Leopold Berchtold v předvečer Velké války. In: Štěpánek, V. (ed.), Velká válka a areálové souvislosti: kultura, literatura a kulturní historie slovanských národů. Brno, Masarykova univerzita, 2014, s. 25-46. 
česko-srbských vztahů. Sborník František Alexandr Zach 1807-2007 (Brno: Albert, 2007, 80 s.) sestavili a redigovali L. Hladký a V. Štěpánek.

\section{Etnografické práce s balkanistickou tematikou na brněnské filozofické fakultě}

Významným př́spěvkem $\mathrm{k}$ řešení balkanologické problematiky jsou také práce brněnských univerzitních etnografů. Byla to zejména monografie Václava Frolce (1934-1992) ${ }^{27}$ Die Volksarchitektur in Westbulgarien im 19. und zu Beginn des 20. Jahrhunderts (Brno: Universita J. E. Purkyně, 1966, 161 s.) a jeho studie o interetnických vztazích v lidovém stavitelství, ${ }^{28}$ o dějinách lidové architektury v Bulharsku, ${ }^{29}$ o bulharsko-srbských vztazích; o sociálních vztazích v lidovém stavitelství aj. České a slovenské balkanistiky se týkaly také jeho referáty na balkanologických sympoziích. Srovnávacím výzkumem balkánské lidové architektury se zabývá Helena Bočková (1952), jež svá bádání kromě řady studií zhodnotila spolu s Jiřím Langrem v monumentální monografii Obydlí v Karpatech a prílehlých oblastech balkánských (Ostrava: Šmíra-Print, 2010, 936 s.). Bočková se etablovala také zkoumáním balkánských minorit v českých zemích. Problematice kulturních svazků rumunské lidové kultury se střední a západní Evropou věnoval několik studií Richard Jeřábek (1931-2006), který zkoumal i kulturní vliv jihoslovanských kolonistů na jižní Moravě. ${ }^{30} \mathrm{Na}$ pomezí historie a etnografie leží i několik výše citovaných editovaných monografií I. Dorovského, zabývajících se osudy makedonských uprchlíků z občanské války v Řecku na území ČR a situací moravských Charvátů, rozsídlených po roce 1948 ze svých původních vesnic, stejně jako monografie Michala Pavláska (1983) S motykou a Pánem Bohem: Po stopách českých evangelíků ve Vojvodině (Brno: Etnologický ústav AV ČR, v. v. i., Praha - pracoviště Brno, 2015, 200 s.), jíž tento historik a etnolog mladší generace, zkoumající zejména kolonizační procesy na pomezí osmanské a habsburské monarchie, rozšíril zá-

${ }^{27}$ O něm více srov. DOROVSKÝ, I. - FROLCOVÁ, V. - NEKUDA, V. (eds.): Vědecký odkaz Václava Frolce. Brno: Muzejní a vlastivědná společnost, 1995.

${ }^{28}$ Např. FROLEC, V.: Zonální formy půdorysu vesnického domu v karpatsko-balkánské oblasti Národopisné aktuality. Strážnice: Krajské středisko lidového umění ve Strážnici, 1989, č. 1, s. 1-13.

${ }^{29}$ Např. FROLEC, V.: Sídla $v$ sofijské oblasti v 19. a počátkem 20. století. In: Sborník prací Filozofické fakulty brněnské univerzity, řada uměnovědná ( $F)$. Brno, Masarykova univerzita, roč. 12, 1963 [vyd. 1964], č. 7, s. 117-137; týž, Vliv rozkladu velkorodiny na vývoj lidového obydlí v západním Bulharsku. Český lid, Praha: Nakladatelství Československé akademie věd, 1965, s. 164-174 aj.

${ }^{30}$ Sestavil např. antologii Moravští Charváti - dějiny a lidová kultura. Brno: Ústav evropské etnologie Masarykovy univerzity, 1991, v níž shromáždil summu textů o dnes již prakticky neexistující menšině čakavských Charvátů na jižní Moravě. 
sadním způsobem poznání o životě evangelické komunity, která přišla v 50. letech 19. století z jihovýchodní Moravy do oblasti Banátu a v současnosti již zaniká. Zcela průkopnickou prací z poslední doby, která nemá v evropské etnologii obdoby, pak je monografie Barbory Machové Bitovo: Každodenní život $v$ makedonských horách (Brno: Masarykova univerzita, 2016, 300 s.) v níž badatelka na základě vlastního terénního výzkumu detailně přiblížila a popsala probíhající vrcholnou fázi zániku starého světa rolnicko-pastevecké kultury Balkánu, která byla pro tyto oblasti určující celá dlouhá staletí.

\section{Literárněvědná balkanistická studia}

Pokud jde o literárněvědnou balkanistiku, lze říci, že se jí v rámci kabinetu balkanistiky a hungaristiky a také ústavu slavistiky soustavně a zásadním způsobem zabýval pouze jediný badatel, totiž Ivan Dorovský. Předmětem jeho zájmu byly od počátku jeho vědecké kariéry zejména problémy makedonské (sám badatel se narodil v dnes již neexistující vesnici Čuka v egejské Makedonii) a také bulharské literatury i vztahy česko-makedonsko-bulharské. Četné jeho práce zabývající se primárně makedonskou problematikou, ale mají i širší srovnávací aspekt slavistický a balkanologický. Patří k nim např. monografie Rajko Žinzifov. Vozdejstvije russkoj i ukrainskoj literatury na jego tvorčestvo (Brno: Univerzita J. E. Purkyně, 1988; také makedonsky jako Vozdejstvoto na ruskata i ukrainskata kniževnos vrz tvoreštvoto na Rajko Žinzifov. Skopje: Makedonska akademija na naukite i umetnostite, 2003, 202 s.), Studii za balkanskiot literaturen proces vo XIX i XX vek (Skopje: Makedonska akademija na naukite i umetnostite, 1992, 217 s.) aj. Některé studie I. Dorovského jsou věnovány pronikání makedonské lidové slovesnosti do českých zemí a otázkám vývoje makedonské literatury. Řecké tematiky se týkají jeho práce o ohlasu řecké revoluce v ruské literatuře a výtvarném umění a o nové a nejnovější řecké literatuře (byl mj. spoluautorem slovníku řeckých spisovatelů (Slovník spisovatelů. Řecko. Praha: Odeon, 1975; 2. vydání Praha: Leda, 2006). Pod jeho vedením také vznikl slovník bulharských spisovatelů (Slovník spisovatelü. Bulharsko. Praha: Odeon, 1978), v jehož rámci publikoval zásadní a dodnes nepřekonanou studii o vývoji bulharské literatury od jejích počátků do doby vydání publikace. Jeho úsilí, aby ve slovníku byli poprvé uvedeni někteří literární tvưrci zejména 19. století jako tzv. dvojdomí nebo mnohodomí (což jsou jeho vlastní termíny pro autory patřící do dějin více národních literatur), nebot podle něj přináležejí jak do dějin bulharské, tak i makedonské literatury, se tehdy setkalo se zásadním odporem bulharských historikủ a literárních historiků. Práce nicméně nakonec po mnoha protivenstvích vyšla. Právě onou dvoudomostí či mnohodomostí balkánských literárních tvůrců, ale také 
problematikou meziliterárních společenství v balkánském prostředí a širšími literárními tématy, zejména komparacím různých etap jihoslovanských literatur, často s přesahy do neslovanských celobalkánských či dokonce mediteránních souvislostí, se Dorovský, jako člen a propagátor slovenské komparatistické školy, založené Dionýzem Ďurišinem (1929-1997), proslavil zejména $\mathrm{v}$ posledních třiceti letech. Tyto tendence jsou patrné jak $\mathrm{v}$ jeho klíčové balkanistické práci nazvané Balkán a Mediterán: literárně historické a teoretické studie (Brno: Masarykova univerzita, 1997, 228 s.), tak v řadě monografií sestavených většinou z několika obsáhlých studií, počínaje prací Balkánské meziliterární společenství (Brno: [s. n.], 1993, 80 s.), přes díla Slované a Evropa (Brno: Masarykova univerzita, 2000, 137 s.), Slovanské meziliterární shody a rozdíly (Brno: Masarykova univerzita, 2004, 157 s.), až po svazek nazvaný Slovanské literatury a dnešek (Brno: Masarykova univerzita, 2008, 240 s.) a některé další. Dorovský ale zevrubně sledoval také recepci jihoslovanských literatur v českém prostředí. Kromě desítek studií s touto tematikou lze zmínit především jeho monografii Recepce literatury jižních Slovanů u nás (Boskovice: Albert, 2003, 83 s.).

Dorovský byl bedlivým pozorovatelem i glosátorem i jednotlivých jihoslovanských literatur. O literatuře makedonské jsme již hovořili. Dlouhodobě se zabýval zkoumáním charvátského dramatu, charvátské moderny, česko-charvátskými literárními kontakty a mapoval recepci charvátské literatury v českých zemích. Důležitá je v tomto smyslu zejména jeho monografie Dramatik Miroslav Krleža (Brno: [s. n.], 1993, 55 s.), v níž se kromě analýzy dramatu jako zásadního žánru Krležovy tvorby věnoval právě recepci umělcových dramat v českém prostředí. Podrobně uveřejnil časopisecky nebo ve sbornících několik desítek studií a statí o bulharské literatuře a dramatické tvorbě, o bulharských literárních tvůrcích a o česko-slovenskobulharských kulturních stycích. Pravidelně sledoval bulharskou odbornou literaturu a referoval o ní v českém odborném i periodickém tisku. Nevyhýbal se ani srbskému literárnímu prostoru a pro četné komparace jej vždy využíval. Publikoval i několik příspěvků o žánrových a typologických otázkách samostatné srbské literatury a vydal řadu studií o recepci děl srbské a černohorské prózy, poezie a dramatu do českého prostředí. Jihoslovanské drama vůbec bylo jeho srdeční záležitostí, jak o tom svědčí nakonec i kniha Dramatické umění jižních. Slovanů I. (1918-1941) (Brno: Masarykova univerzita, 1995, 192 s.), v níž navázal na bádání Franka Wollmana.

Významným počinem brněnské literárněhistorické balkanistiky $\mathrm{v}$ posledním dvacetiletí bylo vydání Slovníku balkánských spisovatelů (Praha: Libri, 2001, 688 s.). Ten sice není pouze dílem brněnské univerzitní balkanistiky, nicméně vznikl pod redakcí I. Dorovského, jenž sepsal úvodní přehledová hesla jednotlivých balkánských literatur a spolu s pracovníky 
ústavu slavistiky Václavem Štěpánkem, Pavlem Krejčím (1971) a Elenou Krejčovou (1973) sestavil většinu hesel.

Kromě mnohovrstevnatého díla Ivana Dorovského se brněnská literárněvědná produkce nemůže $\mathrm{v}$ posledních letech př́liš čím pochlubit. $\mathrm{Za}$ zmínku stojí snad jen přehled vývoje srbské prózy ve studii Václava Štěpánka Vývoj srbské prózy posledních desetiletí (in: Pospíšil, I. (ed.), Klíčové problémy slovanských areálů. Brno: Masarykova univerzita, 2009, s. 73-81) a řada studií o jugoslávském komixu, jíž se v poslední době etabloval mladý badatel Pavel Pilch (1986).

\section{Bibliografické a konferenční aktivity}

Kabinet balkanistiky a hungaristiky byl ve své době také jediným pracovištěm pověřeným vydáváním československé bibliografické produkce z oblasti dějin, literatury, jazyka, etnografie a folkloristiky zabývající se Balkánem, přičemž vydal osm svazků Bibliografie československé balkanistiky (Brno 1970, 1973, 1975, 1978, 1980, 1984, 1988, 1992), ${ }^{31} \mathrm{v}$ nichž byly zachyceny práce od roku 1966 do roku 1990. Na bibliografickou činnost kabinetu pak v roce 2003 navázal Ústav slavistiky Filozofické fakulty Masarykovy univerzity, který ve spolupráci s Historickým ústavem Akademie věd České republiky vydal bibliografii nazvanou České a slovenské odborné práce o jihovýchodní Evropě za léta 1991-2000 (Brno 2003, ed. Ladislav Hladký).

S kabinetem balkanistiky a hungaristiky je také spjata tradice balkanistických symposií. Ty byly zpočátku koncipované jako celostátní, tedy československé - a proto se také sborníky prací z těchto symposií jmenují Studia Balkanica Bohemo-slovaca (1970, 1976, 1987, 1994, 2002, 2006 I.-II.). Jejich počátečním cílem, na němž se doposud nic nezměnilo, bylo především resumovat výsledky české a slovenské balkanistiky a nastiňovat možnosti dalšího zaměření a výzkumu jednotlivých českých a slovenských balkanistických pracovište. První čtyři symposia v letech 1969, 1974, 1986 a 1994, uspořádal kabinet balkanistiky a hungaristiky, další tři, v letech 2001, 2005 a 2016 se pak již konala pod záštitou ústavu slavistiky a dalších brněnských institucí (Moravského zemského muzea, Jihomoravského kraje, Matice moravské či Historického ústavu Akademie věd České republiky a také občanského sdružení Společnosti přátel jižních Slovanů. Pět prvních

${ }^{31}$ Bibliografie vydávaná kabinetem navazovala na Bibliografii československé balkanistiky 1945-1965, vydanou Ústavem dějin evropských socialistických zemí Československé akademie věd v roce 1966 (sestavili Valerián Bystrický, Jiří Hrala, Michal Fedor, Klement Benda. Růžena Dostálová a Růžena Havránková). Jako editoři se při sestavovaní jednotlivých dílů vystřídali, často společně, pracovníci kabinetu hungaristka Marta Romportlová, Ivan Dorovský, Jiří Cvetler, hungarista Richard Pražák a lingvista Jiří Bronec. Bohužel v kompletu nejsou všechny díly k dispozici dokonce ani v Národní knihovně v Praze. 
balkanistických symposií mělo jednoho společného jmenovatele. Tím byl profesor Ivan Dorovský. Všech pět symposií organizoval či spoluorganizoval, všech pět sborníků ze symposií nese pečet jeho redakční práce. Všechny jsou výrazem jeho velké balkanistické erudice a celobalkánského záběru, třetí, čtvrté i páté také jeho košatých vědeckých přátelství. Ostatně to byl právě I. Dorovský, který po předčasné smrti Josefa Kabrdy vedl a organizoval kabinet balkanistiky a hungaristiky a později i počátky balkanistických studií v rámci ústavu slavistiky. Šesté a sedmé symposium pak zorganizovali Pavel Boček (1955), L. Hladký, P. Krejčí (VI. symposium) P. Stehlík (VII. symposium) a V. Štěpánek. Šlo již o široce koncipovaná mezinárodní balkanistická setkání. Na VI. symposiu se s referáty vystoupilo 115 badatelů z České republiky, Slovenska, Rakouska, Slovinska, Charvátska, Bosny a Hercegoviny, Srbska a Černé Hory, Makedonie a Bulharska, na VII. pak 80 přednášejících z České republiky, Slovenska, Srbska, Charvátska, Makedonie, Bulharska a Polska.

Součástí slavistického úsilí všech pracovníků jak kabinetu balkanistiky a hungaristiky, tak později Ústavu slavistiky bylo také aktivní zapojení do publicistické práce, nebot jak se ukazuje, povědomí české veřejnosti o jihoslovanských a vůbec balkánských národech, jejich kultuře i historii je v posledních desetiletích, na rozdíl od meziválečné doby, velmi slabé. Brněnští slavisté zabývající se balkanistikou a jihoslovanským prostředím měli zejména v bolestných letech devadesátých možnost vstupovat do vysvětlovacích kampaní v tisku, rozhlase a televizi, kde nejen vykládali a objasňovali složitosti historického vývoje na Balkáně, ale často také čelili „černobílým” interpretacím zpočátku jen slabě poučených novinářů a publicistů, mnohdy vysloveně stranících té či oné straně konfliktů. Summa summarum lze říci, že činnost vědců a pedagogů filozofické fakulty brněnské univerzity směrem k Balkánu a jihoslovanské problematice byla, je a doufejme, že i zůstane, mimořádně košatá. Dokázala s nadhledem a nestranností vytvářet objektivní díla vysoké odborné úrovně a vychovat také desítky nových absolventů jihoslovanských a balkanistických studií, z nichž mnozí, často i mimo akademickou sféru, přispívají at již jako překladatelé, diplomaté či lidé zabývající se ekonomickými problémy k porozumění mezi českým prostředím a jihoslovanskými národy. 


\section{Библиографија одабраних радова о историји, култури и књижевности јужнословенских народа на Филозофском факултету у Брну}

\section{Монографије}

BOČKOVÁ, H. - LANGER, J.: Obydlí v Karpatech a přilehlých oblastech balkánských. Ostrava: Šmíra-Print, 2010, 936 s.

DOROVSKÝ, I. (ed.): Slovník balkánských spisovatelů. Praha: Libri, 2001, 688 s.

DOROVSKÝ, I. (ed.): Slovník spisovateli̊. Bulharsko. Praha: Odeon, 1978.

DOROVSKÝ, I.: Balkán a Mediterán: literárně historické a teoretické studie. Brno: Masarykova univerzita, 1997, $228 \mathrm{~s}$.

DOROVSKÝ, I.: Balkánské meziliterární společenství. Brno: [s. n.], 1993, 80 s.

DOROVSKÝ, I.: České země a Balkán. Kapitoly z dějin česko-makedonských a makedonsko-českých styků. Brno: Universita J. E. Purkyně - filosofická fakulta, 1973, $250 \mathrm{~s}$.

DOROVSKÝ, I.: Dramatické umění jižních. Slovanů I. (1918-1941). Brno: Masarykova univerzita, 1995, $192 \mathrm{~s}$.

DOROVSKÝ, I.: Dramatik Miroslav Krleža. Brno: [s. n.], 1993, 55 s.

DOROVSKÝ, I.: Konstantin Jireček. Život a dílo. Brno: Universita J. E. Purkyně - filosofická fakulta, 1983, $232 \mathrm{s.}$

DOROVSKÝ, I.: Makedonie: zrození nebo obrození národa?. Boskovice: Albert, 1995, $77 \mathrm{~s}$.

DOROVSKÝ, I.: Rajko Žinzifov. Vozdejstvije russkoj i ukrainskoj literatury na jego tvorčestvo. Brno: Univerzita J. E. Purkyně, 1988; také makedonsky jako Vozdejstvoto na ruskata i ukrainskata kniževnos vrz tvoreštvoto na Rajko Žinzifov. Skopje: Makedonska akademija na naukite i umetnostite, 2003, $202 \mathrm{~s}$.

DOROVSKÝ, I.: Slované a Evropa. Brno: Masarykova univerzita, 2000, $137 \mathrm{~s}$.

DOROVSKÝ, I.: Slovanské literatury a dnešek. Brno: Masarykova univerzita, 2008, 240 s. DOROVSKÝ, I.: Recepce literatury jižních Slovanů u nás. Boskovice: Albert, 2003, $83 \mathrm{~s}$.

DOROVSKÝ, I.: Slovanské meziliterární shody a rozdíly. Brno: Masarykova univerzita, 2004, $157 \mathrm{~s}$.

DOROVSKÝ, I.: Studii za balkanskiot literaturen proces vo XIX i XX vek. Skopje: Makedonska akademija na naukite i umetnostite, 1992, $217 \mathrm{~s}$.

FROLEC, V.: Die Volksarchitektur in Westbulgarien im 19. und zu Beginn des 20. Jahrhunderts. Brno: Universita J. E. Purkyně, 1966, 161 s.

HLADKÝ, L. (ed.): Vztahy Čechů s národy a zeměmi jihovýchodní Evropy. Praha: Historický ústav AV ČR, 2010, $367 \mathrm{~s}$.

HLADKÝ, L.: Bosenská otázka v 19. a 20. století. Brno: Masarykova univerzita, 2005, 388 s.

HLADKÝ, L.: Slovinsko. Praha: Libri, 2010, 190 s.

KABRDA, J.: Le systéme fiscal de léglise orthodoxe dans lEmpire ottoman. Sous le jours des documents turcs. Brno: Opera Universitatis Purkinianae Brunensis. Facultas philosophica, 1969, $321 \mathrm{~s}$. 
KOLEJKA, J.: Národy habsburské monarchie v revoluci 1848-1849. Praha: Svoboda, 1989, 467 s.

KOLEJKA, J.: Balkánská otázka 1908-1914. Mezinárodní socialistické hnutí o mladoturecké revoluci a o balkánských válkách. Brno: Univerzita J. E. Purkyně, 1979, $143 \mathrm{~s}$.

MACŮREK, J.: Dějepisectví evropského východu. Praha: Historický klub, 1946.

MACŮREK, J.: Rumunsko ve své minulosti a prítomnosti. Praha: Orbis, 1930.

MACHOVÁ, B.: Bitovo: Každodenní život v makedonských horách. Brno: Masarykova univerzita, 2016, $300 \mathrm{s.}$

NEČAS, C.: Balkán a česká politika: Pronikání rakousko-uherského imperialismu na Balkán a česká buržoazní politika. Brno: Universita J. E. Purkyně, 1972, 160 s.)

NEČAS, C.: Mezi muslimkami. Působení úředních lékařek $v$ Bosně a Hercegovině v letech 1892-1918. Brno: Masarykova univerzita, 1992, 137 s.

NEČAS, C.: Na prahu české kapitálové expanze. Brno: Univerzita J. E. Purkyně, 1987, $130 \mathrm{~s}$.

NEČAS, C.: Podnikání českých bank v cizině 1898-1918. Rozpínavost českého bankovního kapitálu ve střední, jihovýchodní a východní Evropě v období rakouskouherského imperialismu. Brno: Masarykova univerzita, 1993, 137 s.

Pavlásek, M.: S motykou a Pánem Bohem: Po stopách českých evangelíků ve Vojvodině. Brno: Etnologický ústav AV ČR, v. v. i., Praha - pracoviště Brno, 2015, 200 s.

STEHLÍK, P.: Bosna v chorvatských národně-integračních ideologiích 19. století. Brno: Masarykova univerzita, 2013, 218 s.; překlad do chorvatštiny: Između hrvatstva i jugoslavenstva: Bosna u hrvatskim nacionalno-integracijskim ideologijama 1832-1878. Zagreb: Srednja Europa, 2015, $211 \mathrm{s.}$

ŠTĚPÁNEK, V.: Východní otázka. Od počátkư do konce 60. let 19. století. Brno: Masarykova univerzita, 2014, $150 \mathrm{~s}$.

ŠTĚPÁNEK, V.: Jugoslávie - Srbsko - Kosovo. Kosovská otázka ve 20. století. Brno: Masarykova univerzita, 2011, 472 s.

VILINSKIJ, S. G.: Petko Jurdanov Todorov (život a dílo). Brno: Filosofická fakulta s podporou Ministerstva školství a národní osvěty, 1933, $151 \mathrm{~s}$.

WOLLMAN, F.: a Bulharské drama. Bratislava: FF UK, 1928, 166 s.

WOLLMAN, F.: Dramatika slovanského jihu (Praha: Slovanský ústav, 1930, 248s.

WOLLMAN, F.: Slovesnost Slovanů. Praha: Vesmír, 1928, 263 s.; 2. vydání - Brno: Tribun EU, 2012, 476 s., eds. I. Pospíšil a M. Zelenka.

WOLLMAN, F.: Slovinské drama. Bratislava: FF UK, 1925, 322 s.

WOLLMAN, F.: Srbocharvátské drama. Bratislava: Filosofická fakulta University Komenského [dále jen FF UK], 1924, 408 s.

\section{Студије:}

CVETLER, J.: Český dopisovatel v srbsko-bulharské válce r. 1885. Slovanské historické studie, Praha: Československá akademie věd, 1960, č. 3, s. 263-312.

CVETLER, J.: Die Tätigkeit der tschechischen Juristen in Ostrumelien 1880-1885 als ein Beitrag zum Aufbau des bulgarischen Staates. Association internationale 
d'études du sud-est Européen, Sofia: Éditions de l'Académie Bulgare des science, roč. IV, 1969, s. 665-676.

FROLEC, V.: Sídla $v$ sofijské oblasti v 19. a počátkem 20. století. In: Sborník prací Filozofické fakulty brněnské univerzity, řada uměnovědná (F). Brno, Masarykova univerzita, roč. 12, 1963 [vyd. 1964], č. 7, s. 117-137.

FROLEC, V.: Vliv rozkladu velkorodiny na vývoj lidového obydlí v západním Bulharsku. Český lid, Praha: Nakladatelství Československé akademie věd, 1965, s. 164-174 aj.

FROLEC, V.: Zonální formy půdorysu vesnického domu v karpatsko-balkánské oblasti Národopisné aktuality. Strážnice: Krajské středisko lidového umění ve Strážnici, 1989, č. 1, s. 1-13.

HLADKÝ, L.: Masarykovy problémy s Jihoslovany. In: Evropa mezi Německem a Ruskem. Sborník prací k sedmdesátinám Jaroslava Valenty. Praha, Historický ústav AV ČR, 2000, s. 293-299.

HLADKÝ, L.: Ohlas Masarykova sociálního učení u Slovinců. In: T. G. Masaryk a sociální otázka. Hodonín, Masarykovo muzeum v Hodoníně, 2002, s. 91-99.

HLADKÝ, L.: T. G. Masaryk a jižní Slované: konstanty a proměnné v rámci starého príběhu. In: T. G. Masaryk a Slované. Praha, Historický ústav, 2013, s. 237-252.

HLADKÝ, L.: T. G. Masaryk i Bosna i Hercegovina. (Prilog historiji bosansko-čeških odnosa). Prilozi: Univerzitet u Sarajevu - Institut za istoriju, roč. 30, 2001, s. 117-141.

JORDÁN, F.: Češi a Charváti v tureckých válkách 16. století. In: Sborník prací Filozofické fakulty brněnské univerzity: řada historická (C), Brno, Filosofická fakulta brněnské university, roč. 10, 1961, č. 8, s. 161-173.

JORDÁN, F.: Češi a Slovinci v 19. a na začátku 20. století. (Jejich vztahy veřejné a politické). In: Otázky dějin střední a východní Evropy, Brno, Univerzita J. E. Purkyně, 1971, s. 263-292.

KABRDA, J.: Les problèmes de l'étude de l'histoire de la Bulgarie à l'époque de la domination Turque. Byzantinoslavica, Praha, roč. XV, 1954, č. 2, s. 173-208.

KABRDA, J.: Raja. Izvestija na Bălagarskoto istoričesko družestvo v Sofija, roč. 14-15, 1937, s. 172-185.

KABRDA, J.: Turecké prameny k bulharským dějinám a jejich zpracování $v$ Bulharsku. Časopis Archívní školy, Praha, roč. 15-16, 1939, s. 200-231.

KOLÁŘOVÁ, K.: Časopisy Československo-jihoslovanské ligy: sonda do pramenů k dějinám meziválečných československo-jugoslávských stykủ. Porta Balkanica, Brno: Občanské sdružení Porta Balkanica, roč. 7, 2015, č. 1, s. 47-62.

KOLÁŘOVÁ, K.: Československo-jugoslávské vztahy v meziválečném Brně. Kultúrne dějiny, Rožumberok: Verbum, roč. 7, 2016, č. 2, s. 217-256.

KOLEJKA, J.: „Druhé Rusko” a hnutí jihoslovanských národů 1875-1878. Slovanský přehled, Praha: Academia, roč. 64, 1978, č. 4, s. 302-311.

KOLEJKA, J.: „Východní otázka” nebo „balkánská otázka” v letech 1878-1907: stanovisko mezinárodního socialistického hnutí. In: Sborník prací Filozofické fakulty brněnské univerzity, řada historická (C), Brno, Universita J. E. Purkyně v Brně - filozofická fakulta, roč. 23-24, 1975, č. 21-22, s. 229-290. 
KOLEJKA, J.: „Východní” nebo „balkánská otázka” v 19. století (do r. 1878). Stanovisko mezinárodního socialistického hnutí. In: Hejl, F. - Kolejka J. (eds.), Otázky dějin střední a východní Evropy II. Brno, Univerzita J. E. Purkyně, 1975, s. 149-221.

KOLEJKA, J.: Balkánská otázka v letech 1909-1912. Slovanský přehled, Praha: Academia, roč. 61, 1975, č. 4, s. 265-281.

KOLEJKA, J.: Jižní Slované a Velká východní krize 1875 až 1878. Evropští socialisté o východní otázce. Slovanský přehled, Praha: Academia, roč. 62, 1976, č. 2, s. 111-127.

MACŮREK, J.: Georg Skanderbeg, Albanien und die tschechischen Länder. Studia Albanica, Tirana: Universita d'Etat, 1967, s. 44-51.

MACŮREK, J.: Georg Skanderbeg: Zur 500. Wiederkehr des Todes des grossen Kämpfers des albanischen Volkes für Freiheit und Unabhängigkeit. In: Sborník prací Filosofické fakulty brněnské university, Brno, Filosofická fakulta brněnské university, 1968, $22 \mathrm{~s}$.

MACŮREK, J.: Zwei Entwürfe aus der 2. Hälfte des 15. Jahrhunderts für die Organisierung Europas: des böhmischen Königs Georg von Podiebrad und des moldauischen Fürsten Stephan des Grossen. Revue Roumaine d'Histoire, Bucarest: Académie de la République Socialiste de Roumanie, 1969, s. 502-513.

POSPÍCHAL, J.: Odtažitost a vyčkávání. Vztahy exilových vlád Československa a Jugoslávie v letech 1941-1943. Slovanský přehled, Praha: Academia, roč. 102, 2016, č. 3, s. 451-502.

POSPÍCHAL, J.: Spojenec očima spojence: jugoslávské vojsko v zahraničněpolitických úvahách Československa $v$ letech 1936-1938. In: Sborník vystoupení na studentské konferenci, uspořádané Radou pro mezinárodní vztahy v rámci odkazu celoživotní práce Jiřího Dienstbiera, jejíž VII. ročník se konal 28. května 2013 v Senátu Parlamentu České republiky. Praha, Rada pro mezinárodní vztahy, 2013. s. 26-46.

STEHLÍK, P.: „Srbové všichni a všude”: Karadžićova jazyková definice srbství jako východisko srbského nacionalismu. In: Krejčí, P. - Krejčová E. (eds.), Výuka jihoslovanských jazyků a literatur v dnešní Evropě. Brno, Sojnek, 2015, s. 29-34.

STEHLÍK, P.: Bosna, Zach i Načertanije: O nekim aspektima programa Ilije Garašanina iz 1844. godine. Slavistika, Beograd, roč. 18, 2014, s. 353-360.

STEHLÍK, P.: Bosna a Hercegovina $v$ ideologii chorvatských ustašovců. In: Bosna 1878-2008: Sborník příspěvků z konference konané ve dnech 29.-30. května 2008 v Ústí nad Labem. Ústí nad Labem, Univerzita J. E. Purkyně, 2010, s. 151-161.

STEHLÍK, P.: Makedonsko-albánský spor ohledně založení a činnosti albánské univerzity v Tetovu (1994-2004). Slovanský přehled, Praha: Academia, roč. 92, 2006, č. 3.

STEHLÍK, P.: Slovački apostol jugoslavenstva: Bogoslav Šulek i njegova polemika s Vukom Karadžićem. In: Krejčí, P. - Krejčová, E. (eds.), Bogoslav Šulek a jeho filologické dílo / Bogoslav Šulek i njegov filološki rad. Brno, Česká asociace slavistů - Ústav slavistiky FF MU, 2016, s. 21-28. 
ŠKERLOVÁ, J.: Věrnost za věrnost. Československo-jugoslávské politické vztahy v letech 1929-1934. Přání, rozpory, realita. Praha: Historický ústav AV ČR, 2016, $384 \mathrm{~s}$.

ŠTĚPÁNEK, V.: Církev a stát a Aktuální problémy srbské společnosti. In: Štěpánek, V. (ed.), Současné Srbsko, politika, kultura, Evropská unie. Brno, Albert, 2007, s. 93-101; s. 118-134.

ŠTĚPÁNEK, V.: Několik pohledů na nacionalismus - jeden z faktorů rozpadu Jugoslavie. In: Balkán a nacionalismus. Labyrintem nacionální ideologie. Brno, Porta Balkanica, 2012, s. 39-55.

ŠTĚPÁNEK, V.: Srbské snahy o revizi principů jugoslávské ústavy z roku 1974 (Od konce šedesátých let 20. století do 8. zasedání Ústředního výboru Svazu komunistů Srbska v zárí 1987). Slovanské historické studie, roč. 31, 2006, 101-136.

ŠTĚPÁNEK, V.: Česká kolonizace Banátské vojenské hranice na území srbsko-banátského hraničářského pluku. In: Od Moravy k Moravě. Z historie česko-srbských vztahů v 19. a 20. století. Brno, Matice moravská, 2005, s. 73-102.

ŠTĚPÁNEK, V.: Failed Attempts to Improve Relations between Serbia and Austria-Hungary on the Eve of the First World War as Reflected in Czech Archival Records. In: The Serbs and the First World War 1914-1918. Belgrade, Serbian Academy of Sciencea and Arts, 2015, s. 219-234.

ŠTĚPÁNEK, V.: Neúspěšné pokusy o smír - česká politická reprezentace, Nikola Pašić a Leopold Berchtold v předvečer Velké války. In: Štěpánek, V. (ed.), Velká válka a areálové souvislosti: kultura, literatura a kulturní historie slovanských národů. Brno, Masarykova univerzita, 2014, s. 25-46.

ŠTĚPÁNEK, V.: Tomáš G. Masaryk a Srbové z království před první světovou válkou. In: Doubek, V. - Hladký, L. - Vlček, R. (eds.), T. G. Masaryk a Slované. Praha, Historický ústav, 2013, 297-312.

ŠTĚPÁNEK, V.: VIII. zasedání Ústředního výboru Svazu komunistů Srbska-přelomové datum moderní jugoslávské historie. Př́spěvek k objasnění mocenského vzestupu Slobodana Miloševiće. Studia historica Brunensia, roč. 53 2005, s. 179-194.

ŠTĚPÁNEK, V.: Vývoj srbské prózy posledních desetiletí (in: Pospíšil, I. (ed.), Klícové problémy slovanských areálů. Brno: Masarykova univerzita, 2009, s. 73-81)

WOLLMAN, F.: Njegošův deseterac. Slavia: Praha, roč. 9, 1930-1931, č. 4, s. 737-791.

ZEMAN, P.: Čeští učitelé na gymnáziích v Bulharsku v letech 1878-1912. In: Przybylski, M. - Šaur, J. (eds.), Mladá slavistika: současné trendy ve výzkumu slovanských literatur, jazyků a kultur. Brno, Masarykova univerzita, 2014. s. 147-162 aj.

ZEMAN, P.: Motivy české inteligence k př́chodu do Bulharska. In: Čolakova, Ž. - Avramova, C. - Burova, A. - Borislov, B. - Kuzmova, M. - Dimitrova, S., Sbornik s dokladi ot petata nacionalna srešta na bochemistite. Plovdiv, Universitetsko izdatelstvo „Paisij Chilendarski”, 2016, s. 63-72. 


\section{Зборници и колективне монографије}

František Alexandr Zach 1807-2007. Brno: Albert, 2007, 80 s., eds. Hladký, L. Štěpánek, V.

Charváti ještě žijí mezi námi. Brno: Společnost přátel jižních Slovanů v České republice, 1996, 123 s., ed. Dorovský, I.

Ilinden je v nás. Brno: Albert, 2003, 117 s., ed. Dorovský, I.

Makedonci žiji mezi námi I. a II. Brno: Společnost přátel jižních Slovanů, 1998, 351 s.; Brno - Boskovice: Společnost přátel jižních Slovanů a Albert, 2008, 227 s., ed. Dorovský, I.

Moravští Charváti - dějiny a lidová kultura. Brno: Ústav evropské etnologie Masarykovy univerzity, 1991, ed. Jeřábek, R.

Od Moravy k Moravě I. Brno: Matice moravská ve spolupráci s Maticí srbskou, 2005, 312 s., eds. Hladký, L. - Štěpánek, V.

Od Moravy k Moravě II. Novi Sad: Matice srbská ve spolupráci s Maticí moravskou, 2011, 430 s. ed. české části Štěpánek, V.

Současné Srbsko - politika, kultura, EU. Brno: Albert, 2007, 160 s., ed. Štěpánek, V.

Studia Balkanica Bohemoslovaca I. Brno: Univerzita J. E. Purkyně, 1979, 480 s., eds. Dorovský, I. - Pražák, R.

Studia Balkanica Bohemoslovaca II. Brno: Univerzita J. E. Purkyně, 1978, 400 s., ed. Dorovský, I.

Studia Balkanica Bohemoslovaca III. Brno: Univerzita J. E. Purkyně, 1987, 334 s., ed. Dorovský, I.

Studia Balkanica Bohemoslovaca IV. Brno: Masarykova univerzita, 1995, 218 s., ed. Dorovský, I.

Studia Balkanica Bohemoslovaca V. Brno: Masarykova univerzita, 2002, 321s., ed. Dorovský, I.

Studia Balkanica Bohemoslovaca VI. Brno: Masarykova univerzita, 2005, 1164 s., eds. Štěpánek, V. - Boček, P. - Hladký, L. - Krejčí, P. - Stehlík P.

\section{Библиографија:}

Bibliografie československé balkanistiky 1945-1965. Praha: Ústav dějin evropských socialistických zemí Československé akademie věd, 1966, 117 s., eds. Bystrický, V., Hrala, J., Fedor, M., Benda, K., Dostálová, R., Havránková, R.

Bibliografie československé balkanistiky za léta 1966-1968. Brno: Filozofická fakulta Univerzity Jana Evengelisty Purkyně, 1970, 83s. Eds. Pražák, R., Dorovský, I., Šaur, V., Romportlová, M.

Bibliografie československé balkanistiky 1969-1971. Brno: Univerzita Jana Evangelisty Purkyně, 1973, 155 s., eds. Dorovský, I., Romportlová, M.

Bibliografie československé balkanistiky 1972-1974. Brno: Univerzita Jana Evangelisty Purkyně, 1975, 196 s., eds. Dorovský, I, Romportlová, M.

Bibliografie československé balkanistiky za léta 1975-1977. Brno: Univerzita Jana Evangelisty Purkyně, 1980, 224 s., eds. Cvetler, J., Dorovský, I., Romportlová, $M$. 
Bibliografie československé balkanistiky za léta 1978-1982. Brno: Univerzita Jana Evangelisty Purkyně, 1984, 280 s., eds. Cvetler, J., Dorovský, I., Romportlová, $M$.

Bibliografie československé balkanistiky za léta 1983-1986. Brno: Univerzita Jana Evangelisty Purkyně, 1988, 209 s., eds. Cvetler, J., Dorovský, I., Komárková, J., Romportlová, $M$.

Bibliografie československé balkanistiky za léta 1987-1990. Brno: Masarykova univerzita, 1992, 232 s., eds. Bronec, J., Cvetler, J., Dorovský, I., Raev, I.

České a slovenské odborné práce o jihovýchodní Evropě za léta 1991-2000. Brno: Ústav slavistiky Filozofické fakulty Masarykovy univerzity ve spolupráci s Historickým ústavem AV ČR, 2003, 400 s., ed. Ladislav Hladký.

Радови посвећени брњенским славистима, проучаваоцима јужнословенске проблематике:

DOROVSKÝ, I. - FROLCOVÁ, V. - NEKUDA, V. (eds.): Vědecký odkaz Václava Frolce. Brno: Muzejní a vlastivědná společnost, 1995.

HLADKÝ, L.: Jižní Slované a Balkán v díle Josefa Kolejky. In: Historik Josef Kolejka. Brno, Masarykova univerzita a Společnost přátel jižních Slovanů, 2004, s. 21-25.

HLÔŠKOVÁ, H. - POSPÍŠIL, I. - ZELENKOVÁ, A.: Slavista Jiři Horák v kontexte literatúry a folklóru. Brno: Česká asociace slavistů, 2012, 265 s.

POSPÍŠIL, I. - ZELENKA, M.: Střední Evropa jako křižovatka metodologií: Slovesnost Slovanů Franka Wollmana - tradice a souvislosti (nad druhým českým vydáním). In: Wollman, F., Slovesnost Slovanů. Brno, Tribun EU, s. 23-68.

POSPÍŠIL, I.: Brněnský prǐběh Sergije Vilinského. In: Migrácia obyvatelov východnej Európy na územie Slovenska a Čiech (prvá polovica 20. storočia). Prešov, Filozofická fakulta Prešovskej univerzity, 2009, s. 186-193.

PRAŽÁK, R.: Josef Kabrda (3. II. 1906-27. V. 1968. Život a dílo. In: Sborník prací filosofické fakulty brněnské university, Brno, Universita J. E. Purkyně, 1969, C 16, s. 7-30.

VLČEK, R.: Josef Macưrek. Praha: Akademie věd České republiky [dále jen AV ČR], 2015.

\section{Радови посвећени организацији јужнословенских и балканистичких студија:}

HLADKÝ, L.: Balkanistika - předmèt zkoumání, historie a současnost této vědní specializace. In: Semotamová, E. (ed.), Cestou dějin. K poctě prof. PhDr. Svatavy Rakové, CSc. Praha, Historický ústav AV ČR, 2007, s. 77-88.

HLADKÝ, L.: Př́spěvek $k$ dějinám české historické balkanistiky. Tradice tzv. brněnského střediska. In: Historik na Moravě. Profesoru Jiřímu Malírovi, předsedovi Matice moravské a vedoucímu Historického ústavu FF MU, věnují jeho kolegové, prátelé a žáci k šedesátinám. Brno, Matice moravská, 2009 s. 195-206. 
KREJČÍ, P.: Problematika výuky jihoslovanských jazyků na Filozofické fakultě Masarykovy univerzity. In: Pospíšil, I. - Zelenka, M. (eds.), Česká slavistika 2008. Brno - Praha, Česká asociace slavistů, Literárněvědná společnost, pobočka Praha, Academicus, 2008, s. 91-100.

KREJČÍ, P.: Seminář jihoslovanských filologií a balkanistiky. In: Pospíšil, I. (ed.)., Ústav slavistiky FF MU. Východiska - koncepce - výhledy. Brno, ČižmárPartner, 2005, s. 37-48.

Václav Štěpánek

\author{
RESEARCH ON HISTORY, CULTURE AND LITERATURE \\ OF SOUTH-SLAVONIC NATIONS AT THE FACULTY OF ARTS \\ OF THE MASARYK UNIVERSITY OF BRNO (CZE)
}

\begin{abstract}
Summary
Presented paper gives the research survey, achieved in the field of history, culture, and literature of South-Slavonic nation at the Faculty of Arts of Brno since its establishment in 1919 up till now. It gives information on institutionalization of South-Slavonic (and Balkan Studies) at the Masaryk University. We are immortalizing and listing the most famous personalities of the Slavistics in Brno, who brought the important research achievements in this field and drew attention to the principal results of scholarly production of both Slavonic and Balkan Studies oriented scholars in Brno. We state, that activities of both scholars and professors of the Faculty of Arts focused to Balkans and South-Slavonic topics was and remains extraordinarily opulent. Slavonic Studies in Brno demonstrated to create open-minded objective works featured with all high professional level, detachment and balance, as well as to educate dozens of new alumni within South-Slavonic and Balkan Studies, numerous of which, often even out of academic sphere, are contributing to understanding among Czech and South Slavonic nations being translators, diplomats and/or professionals engaged in economic matters.

Key words: Slavonic studies, Southern Slavs, South Slavic studies, Balkanology, Brno, Masaryk University
\end{abstract}

